\title{
Enhancing the Concept of Numbers in Kindergarten with Graphic Media and Montessori Approachment
}

\author{
Dahniarti C. Rety ${ }^{1, a^{*}}$, Siti Masitoh ${ }^{1, b}$, and Fajar Arianto $1, c$ \\ 1Department of Educational Technology, State University of Surabaya, Surabaya, 60213, Indonesia \\ a dahniarti.17070905015@mhs.unesa.ac.id \\ *Corresponding Author \\ Whatsapp number: [081332523736]
}

How to Cite : Rety, D., C., Masitoh, S., Arianto, F. (2020). Enhancing the Concept of Numbers in Kindergarten with Graphic Media and Montessori Approachment. International Journal for Educational and Vocational Studies, 2 (1), 86-90. DOI: https://doi.org/10.29103/ijevs.v2i1.2021

\section{ARTICLE HISTORY}

Received: 12 October 2019

Revised: 11 December 2019

Accepted: 26 January 2020

\section{KEYWORDS}

Concept number;

Graphic media;

Montessori approachment;

\begin{abstract}
The background of this study by the achievement of cognitive development in this case the introduction of the concept of numbers has not been achieved. Problems that exist in group A Christian kindergarten LOGOS, when spelling out there are still children who haven't spelled out exactly, there are objects that are missed when spelling out and have not been able to show many objects in accordance with the symbol numbers, especially numbers $5,6,7,8,9,10$, this happens because there is no media in accordance with the theme of the lesson (land animals) and the method used is still in the form of assignments. The purpose of this study is to describe the increase in children's ability to recognize the concept of numbers through the use of graphic media and three-stage learning methods in the learning process. This study uses a class action research (CAR) method which is carried out in two cycles. Each cycle consists of four stages, namely the planning stage, the implementation phase, the observation and reflection stage. The subjects of the study were children of Group A Christian LOGOS Kindergarten consisting of 17 children. Data collection techniques in this study through observation and documentation. The results of the first cycle and second cycle of research showed an increase. The results showed that the use of graphic media and three-stage learning methods can improve the ability of children to recognize the concept of numbers, especially the numbers $5,6,7,8,9,10$ in group A children of Christian Kindergarten LOGOS.
\end{abstract}

This is an open access article under the CC-BY-SA license.

\section{INTRODUCTION}

Early Childhood Education is the basis for further development of education. In the development of Early Childhood Education, several developments that must be considered and become an integrated whole consist of spiritual, social emotional, physical motor, cognitive, language, and art to obtain good development for early childhood. Early childhood development can be said to develop well if all aspects of development can be achieved. Every child has different characteristics as well as in the achievement of development. Achievement of development in early childhood has a standard that has been determined in Peraturan Menteri Pendidikan dan Kebudayaan (Permendikbud) 137 of 2014, concerning the Standard of the Level of Achievement of Child Development (STPPA). In the aspect of cognitive development, one of the abilities developed in early childhood in the age range of 4-5 years is to recognize the concept of numbers. In accordance with the
Standar Tingkat Pencapaian Perkembangan Anak (STPPA) early childhood age range $4-5$ years in recognizing the concept of numbers is 1 ) to say many objects one to ten, 2) recognize the concept of numbers 3) recognize symbols. Buys, 1999 Numbers represent a very broad field of knowledge and are interesting things to always be repeated. Treffers, 1999 Children will be faced with many situations that can make direct experience namely by the sounds, symbols, and meanings associated with numbers. Knowledge about mathematics can be introduced to early childhood (birth age - 6 years) can be done with games and to develop the concept of numbers using numbers in various activities (Lestari, 2011).

The concept of numbers is the beginning of the introduction of mathematics in subsequent mathematics learning. The experience of recognizing the concept of numbers in early childhood through concrete exploration of 
objects. Getting to know numbers really needs to be taught early on. According to Susanto, 2014 to introduce the concept of numbers required the right media and methods.

The method determined must be in accordance with the stages and principles of numeracy development in children. Sadiman, et al. 1993. The media is an intermediary or introduction to the recipient of the message. Graphic media is visual media that can be used to deliver messages to recipients using visual communication symbols. Several types of graphic media: pictures / photographs, sketches, diagrams, charts / charts, cartoons, posters, maps and globes, flannel boards, bulletin boards. The media are intermediaries and means of communication (Smaldino, Lowther, and Russell, 2014:7). Graphic media is a medium used in teaching that combines real things with ideas or ideas that clearly combine words and images. Good grafic media can develop children's imagination (Sudjana and Rivai, 2017: 20). According to Moeslichatoen, 2004:7 methods are part of the strategy in an activity and the means used to achieve goals. According to Santoso, 2017 there are three approaches that can be done in learning according to the situation, goals, level of maturity, and ethics, namely: authoritarian, permissive, and democratic. According to the Directorate of Early Childhood Education (Susanto, 2017:121) several methods used in early childhood learning are: telling stories, singing, traveling, role playing, modeling, assigning tasks, project methods, habituation methods, conversational methods, and practice. According to Montesorri (Gettman, 2016:107) sensory activity is an activity that can be used to assist children in choosing a variety of experiences gained through the senses possessed by humans. Through sensory activities, children are expected to be able to develop, organize, expand and nurture. In sensory activities there are three stages of learning: in the early stages of conveying components by showing objects and recognizing, the second stage connects what has been said with what is presented, providing context and quality in what is presented. Motessori devide 3 steps for learning a). The first stage: is to hold the recognition of an identity in this case connecting the object indicated by the name of the object. b). The second stage: is the stage recognition and comparison, at this stage to ensure that the child is able or understanding. c). The third stage: is to distinguish the same objects. At this stage done so that children can really remember the name of the object. In this three-step learning process, it is done in teaching new concepts through repetition. This can help children to better understand the material presented. This method can help teachers know how much their children understand what has been taught.

In Christian LOGOS kindergarten in the 4-5 years age group or TK A in recognizing the concept of numbers there are some children who have not yet reached development. At the time of counting there were still children who did not count precisely, there were objects that were missed when numerating and were not able to show many objects according to the symbol numbers, especially numbers 5,6 , $7,8,9,10$. There was no media in accordance with the theme of the lesson (land animals). Given the above problems, this study aims to improve the introduction of the concept of numbers by using media and the learning methods used. The media used are graphic media and the method used is a three-stage learning method.

\section{METHODS}

This study aims to increase the introduction of the concept of numbers in children aged 4-5 years or TK A, so the type of research used in this study is Classroom Action Research (PTK). The study was conducted at LOGOS Christian School. The research subjects were all kindergarten A children aged 4-5 years, total 17 children. The Kemmis and Mc. Tanggart consists of four components, namely: 1) planning 2) implementation 3) observation / observation 4) Reflection. Introduction to the concept of numbers using graphic media and three-stage learning methods. In this study the data collection techniques used were observation and documentation. The study was conducted using observation sheets. Observation is a data collection technique more specific and not limited to people but to other natural objects (Sugiyono, 2011). The documentation technique is used to find data about variables.

\section{RESULTS AND DISCUSSION}

\subsection{Learning Planning}

Before action research is carried out, systematic planning is first arranged so that it can facilitate the researchers in implementing the action. The planning is as follows:

\subsubsection{Preparing learning media}

Prepare graphic media that will be used, namely pictures of animals in accordance with the learning theme.

\subsubsection{Setting up RPPH}

Prepare a learning plan that will be used which determines the learning method used, namely by learning three stages.

\subsubsection{Preparing the Instrument}

Implementation of the action is accompanied by observation so that the instrument is needed. The classroom action research observation instrument contains indicators that illustrate the successes and shortcomings of the whole action in increasing the introduction of the concept of numbers.

\subsection{Learning Implementation Using Graphic Media and Three-Stage Learning.}

Learning three stages:

\subsubsection{Stage one}

1) The teacher tells about animals according to the theme of learning in class. 2) The teacher shows pictures of 
animals when telling stories according to the learning theme, mentions the name of the animal, the color of the animal, and the sound of the animal. 3) The teacher asks students to repeat what has been mentioned by the teacher. 4) The teacher asks students to follow the animal counting together.5) The teacher connects with the symbol number. 6) The teacher mentions the symbol of numbers and asks students to pay attention to the symbol of numbers and mentions, repeated several times. 7) The teacher invites students to sing songs according to animal themes

\subsubsection{Stage two}

1) The teacher shows pictures of animals to students. 2) The teacher mentions the color and size of the animal. 3) Learners spell out pictures of animals and connect with symbol numbers.

\subsubsection{Stage Three}

- Teachers give questions to students:

- What is the name of the animal?

- What color is it?

- How many animal?

- The teacher asks students to designate the symbol of the numbers mentioned.

\subsection{Observation}

Getting to know the concept of numbers is one of the achievements of children's development at the age of 4-5 years. Achieving this development is in accordance with Standar Tingkat Pencapaian Perkembangan Anak (STPPA) contained in Permendikbud No. 137 of 2014, recognizing symbols of numbers (numbers), numerating 1 to 10 , and connecting the symbols of numbers with the number of objects. Here is a picture of the recapitulation of the results of observations of children's ability to recognize the symbol of numbers from cycle I to II:
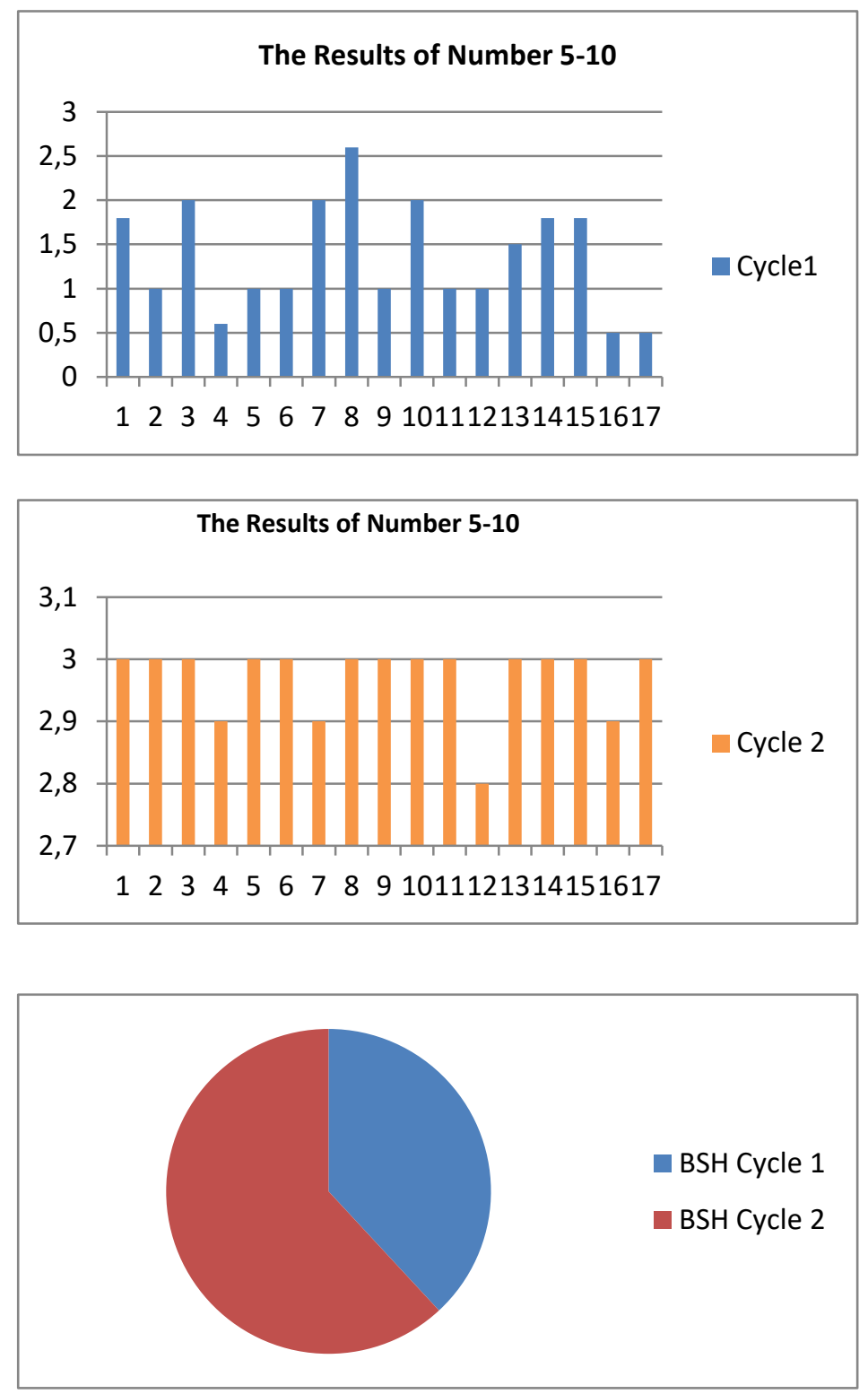
At the beginning, the children in counting are still not able to count precisely, there are still things that are missed and still cannot show the number of objects in accordance with the symbol number. According to Montessori, (Britton 2018: 185-186) Mathematics relates to circles and abstract symbols that can be used to express so that they can communicate with others. Three stages in learning about numbers: 1) sort out in groups, before identifying, children need to understand objects, can be grouped and recognize the properties of objects. 2). pair or match one group of objects with another group. 3). comparing, a child needs to understand more and less. To be able to understand the stages of learning about numbers requires a play situation before learning formally with a number symbol. The media used is also not in accordance with the theme of the lesson so that children have no interest in counting. In the first cycle where using graphic media according to the theme of the lesson, children began to be interested in spelling out, even though there were not many children developing to achieve it. In the second cycle, using graphic media and a three-stage learning method, the achievement of Berkembang Sesuai Harapan (BSH) is increased. This is as stated by Safei, using graphic media is one of the solutions in the oral learning process in classroom learning. Using grafic media in the learning process will attract children's attention and clarify the material presented. Yaumi (2018:132) uses pictures in the learning process of children to pay more attention and increase children's creativity and be more enthusiastic in learning. Kurniati, Ali, and Halida, (2013: 4) in the learning process can use pictures that contain information in words and numbers. The existence of something new can make children more willing to learn, especially with the media provided in the learning process. Attractive media can make children interested in learning. Thus according to Masyrofah, 2017 children have the desire to look for something new to do, activities that have a level of difficulty children will always look for something new to do that is good and challenging. With the interesting media, children are interested in seeing pictures of animals and making children's attention focused on the images presented. Hurlock (Susanto, 2014:107) the development of numbers at first, states the concept that children begin to understand with the increasing experience of children, namely the concept of numbers. Concept of numbers are related to words. Montessori (Gutex, 2015:359), the need for exercises in number recognition. Exercises in the form of practical activities and sensory activities. Sensory activities equip children in basic skills in mathematical tasks.The experiences experienced by children will influence the concept of numbers. The three-step learning method that is carried out can make it easier for children to learn a concept. In addition to directly seeing pictures and recognizing pictures, children also increasingly understand the repetition that is done. Even this can help teachers to understand children's understanding.

\subsection{Reflection}

Based on observations during action research, the media used are very good and interesting for children to see pictures of animals and the number of animals and the three-stage learning method is very helpful for children in stimulating the introduction of the concept of numbers, in cycle I there are still children still unable to focus attention picture and numerate so that improvements are made in the use of learning methods used in cycle II.

After the use of graphic media the results obtained in the pre-action change, in the first cycle the criteria of Belum Berkembang (BB) there are 3 children, the criteria for Mulai Berkembang (MB) there are 6 children and the criteria for Berkembang Sesuai Harapan (BSH) there are 8 children. In contrast to the results in cycle II, the criteria for Mulai Berkembang (MB) there are 4 children and the criteria for Berkembang Sesuai Harapan (BSH) there are 13 children. The results of the second cycle show that the ability of children on indicators to recognize the concept of numbers has developed optimally. Can be seen in the previous indicator, the indicator results say 5 to 10 look better. In the previous indicator in the first cycle there were still results with the criteria of Belum Berkembang (BB) there were 3 children, where as in the second cycle the improvement was better there were no results with the criteria of Belum Berkembang (BB), the criteria for Starting to develop were reduced there were results of 4 children from the previous results there are 6 children. An increase in the criteria of BerKembang Sesuai Harapan (BSH) resulted in 13 children. In cycle II the criteria Berkembang Sesuai harapan (BSH) more than cycle I.

Thus it can be concluded that the use of graphic media and three-stage learning methods can improve children's ability to recognize the concept of numbers in group A in Christian LOGOS Kindergarten.

\section{CONCLUSION}

Based on the results of the Classroom Action Research (PTK) which was carried out 2 cycles, about increasing the ability of children to recognize the concept of numbers through graphical media and three-stage learning methods in children in Group A Christian Kindergarten LOGOS compiled by researchers in accordance with the success criteria. Researchers make a Rencana Pelaksanaan Pembelajaran Harian (RPPH) as a guide in implementing learning.

In the planning of learning carried out in 2 cycles. With the initial findings where there are still many children who have not yet reached the child's development in recognizing the concept of numbers. In the implementation of learning, cycle 1 is done learning using graphic media and three stages of learning there are some children achieving the results of Developing in line with Expectations but there are still many children who have not achieved these results. Thus, the next learning implementation is cycle 2 and results are obtained better 
than cycle 1, where the achievement of Developing in Accordance with Expectations is greater and there are no Underdeveloped achievements. Achievement of learning the introduction of the concept of Numbers in children Group A children has increased from cycle I to cycle II, this occurs an improvement in the second cycle in reducing obstacles in the learning process. The use of graphic media and the three-stage learning method were chosen to increase the introduction of the concept of numbers. An increase in the introduction of the concept of numbers is increasing and achieving optimal results, there are children on average are in the criteria of Berkembang Sesuai Harapan (BSH). The choice of graphic media and three-step learning methods according to the needs and characteristics of the child.

\section{REFERENCES}

Britton .L, (2018). Montessori play adn Learn. Jakarta: Bentang Pustaka.

Elytasari .S. (2017). Esensi Metode Montessori Dalam Pembelajaran Anak Usia Dini. Email: lytadian@gmail.com. Jurnal Volume III. Nomor 1. Januari - Juni 2017

Gettman . D. (2016). Metode Pengajaran Montessori Tingkat Dasar. Yogyakarta: Pustaka Pelajar.

Edited by Gutek, L.G (2015). "Metode Montessori: Panduan Wajib untuk Guru dan Orangtua Didik PAUD (Pendidikan Anak Usia Dini)". Yogyakarta: Pustaka Pelajar

Kemmis, S and McTaggart, R. (1992). The Action Research Planner (3rd ed.s.l. Geelong: Deakin University Press.

Kurniati, Ali, dan Halida, (2013). "Peningkatan Kemampuan Mengenal Konsep Bilangan Melalui Kartu Angka Bergambar di TK Idhata 1 Ketapang, PG-PAUD”. Jurnal Pendidikan dan Pembelajaran.

Lestari, (2011). "Konsep Matematika untuk Anak Usia Dini". Direktorat Pembinaan Pendidikan Anak Usia Dini Direktorat Jenderal Pendidikan Anak Usia Dini Nonformal dan Informal Kementerian Pendidikan Nasional.

Mendikbud. (2014). Standar Nasional Pendidikan Anak Usia Dini. Jakarta: Mendikbud

Moeslichatoen. (2004). Metode Pengajaran Di Taman Kanak-Kanak.

Mursiami . R. Penggunaan Media Grafis Untuk Meningkatkan Hasil Belajar IPS Pada Materi Teknologi Produksi, Komunikasi Dan Transportasi Pada Siswa Kelas IV SD Anugrah Surabaya. Jurnal PGSD FIP Universitas Negeri Surabaya.

Masyrofah, (2017). Model Pembelajaran Montessori Anak Usia Dini. Jurnal Vol. 2 No. 2, Juli - Desember 2017 Jurnal Pendidikan Anak Usia Dini.
Safei, (2007) Penggunaan Media Grafis Dalam Proses Pembelajaran. Jurnal Lentera Pendidikan. Edisi X, No. 1 Juni 2007 (116-123).

Sadiman, dkk. (1993). Media Pendidikan: Pengertian, Pengembangan, dan Pemanfaatnya. Jakarta : PT. Raja Grafindo Persada.

Smaldino, Lowther, and Rusell, (2014). Instructional Technology \& Media For Learning.

Susanto Ahmad. (2014). Perkembangan Anak Usia Dini. Jakarta: Kencana Prenadamedia Group.

Susanto Ahmad. (2017). Pendidikan Anak Usia Dini. Jakarta : PT Bumi Aksara.

Sugiyono. (2011). Metode Penelitian Kuantitatif, Kualitatif dan R \& D. Bandung: Penerbit Alfabeta.

Sudjana N. And Rivai A. (2017). Media Pengajaran. Bandung: Penerbit Sinar Baru Algensindo

Treffers .A, Panhuizen and Buys K. (2001). Children Learn Mathematics. Netherlands: Wolters Noordhoff.

Yaumi, M., (2018) Media \& Teknologi Pembelajaran, Jakarta: Prenadamedia Group. 